\title{
Analisis Pengaruh Service Quality dan Biaya Terhadap Kepuasan pelanggan (Study Kasus Pada PT. Mustikasakti Sarana Kencana)
}

\author{
Ivan Reyhansyah ${ }^{1^{*}}$ \\ ${ }^{1}$ Prodi Transportasi, Sekolah Tinggi Maritim Yogyakarta, Jl. Magelang KM 4.4, \\ Yogyakarta 55284, Indonesia \\ *Corresponding Author.Email:ivanreyhansyahstimaryo@ gmail.com. Telp : 08111985353
}

\begin{abstract}
Abstrak
Penelitian ini bertujuan untuk menganalisis pengaruh kualitas pelayanan dan harga terhadap kepuasan pelanggan dengan obyek PT. Mustikasakti Sarana Kencana. Metode kwantitatif korelasional, pengumpulan data dengan survey pelanggan sebanyak 49 responden layak dianalisis. Hasilnya kualitas pelayanan berpengaruh positif terhadap kepuasan pelanggan, dan kepuasan pelanggan berpengaruh positif terhadap loyalitas pelanggan.

Kata Kunci: Kualitas pelayanan, kepuasan pelanggan, kesetiaan pelanggan

Abstract

The aim study to analize influence service quality to customer satisfaction on PT. Mustikasakti Sarana Kencana. Method use by corelation, data collecting by survey on 49 respondent. The result point out that service quality influenced to customer satisfaction, then customer satisfaction influenced to customer loyalty. tant, spesific, or representative for the article
\end{abstract}

Keyword: Service quality, customer satisfaction, customer loyalty

\section{PENDAHULUAN}

Transportasi merupakan salah satu mata rantai yang sangat vital dalam suatu kegiatan perekonomian pada suatu negara. Tanpa adanya transportasi sebagai sarana penunjang maka tidak dapat diharapkan tercapainya suatu hasil yang maksimum dan memuaskan bagi perkembangan ekonomi di negara tersebut (Rodrigue, Comtois and Slack, 2006).

Terkait dengan pentingnya fungsi transportasi dalam perekonomian masyarakat maka muncul banyak perusahaan freight forwarding, yang salah satu jasa yang ditawarkan adalah transportasi bagi pengirim barang (Undang-Undang Nomor 17 Tahun 2008). Sebagai perusahaan yang berorientasi keuntungan, perusahaan freight forwarding mempunyai perhatian pada pelanggan, karena pelanggan merupakan mitra utama yang terus harus dilayani dengan baik (Porter, 1980; Kotler and Amstrong, 1994). Salah satu perusahaan tersebut adalah PT. Mustikasakti Saranakencana yang memiliki komitmen memberikan pelayanan terbaik bagi para pengguna jasanya, di tengah munculnya perusahaan lain sejenis. 
Pemberian pelayanan terbaik kepada pelanggan adalah merupakan strategi bersaing unggul (Porter, 1980).

Pelayanan yang baik kepada pelanggan ditengarai berkontribusi terhadap kepuasan pelanggan. Hal ini ditunjukkan pada kinerja perusahaan memenuhi kebutuhan dan keinginan pelanggan, salah satunya adalah dalam hal ketepatan waktu pengiriman barang dengan aman sampai tujuan. Kebutuhan dan keinginan pelanggan yang terpenuhi berarti perusahaan dapat memberikan nilai yang bermakna bagi pelanggan. Menurut Christopher (2011), nilai diwujudkan dalam bentuk rumus sebagai berikut.

\section{Fungsi teknis produk $x$ Komitmen mutu penjual}

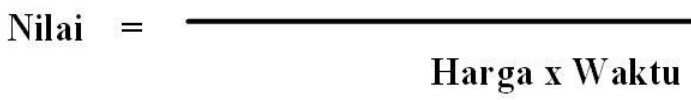

Rumus tersebut menunjukkan rasio antara fungsi teknis produk jasa yang ditawarkan produsen kali komitmen mutu yang dijanjikan dibagai biaya yang dikeluarkan konsumen kali waktu. Maka nilai di sini orientasinya adalah kepuasan konsumen atas produk atau jasa yang dibeli pelanggan. $I$

Permasalahan dihadapi oleh PT. Mustikasakti Saranakencana adalah: (1) Kualitas pelayanan selama ini masih sering menimbulkan kekecewaan dan komplain terhadap jadwal pengiriman barang, (2) Ketidaksesuaian pencapaian kualitas pelayanan berpengaruh terhadap kepuasan pelanggan, (3) Jika kepuasan pelanggan rendah dapat melemahkan kesetiaan pelanggan, (4) Harga yang ditawarkan apakah dapat memberikan pelayanan sesuai kriteria kesetiaan pelanggan.

Berdasarkan uraian di atas maka peneliti ingin menguji kualitas pelayanan perusahaan freight forwading terhadap kepuasan pelanggan dan kesetiaan pelanggan.

\section{KAJIAN LITERATUR}

\section{Konsep Freight Forwarding}

Sesuai Undang-Undang Nomor 17 Tahun 2008, kegiatan perusahaan freight forwarding (FF) diakomodir. Artinya regulasi ini mewadahi semua kegiatan terkait angkutan laut atau pelayaran termasuk kegiatan kegiatan pendukungnya seperti halnya perusahaan FF. Batasan umum FF adalah usaha yang fungsinya merupakan "wakil" dari shipper atau consignee dalam pengiriman barang. FF beroperasi berdasarkan Undang-Undang Nomor 17 Tahun 2008 tentang Pelayaran dan Peraturan Menteri Perhubungan Nomor 49 Tahun 2017 tentang Penyelenggaraan dan Pengusahaan Jasa Pengurusan Transportasi. FF juga disebut non-vessel operating common carrier (NVOCC), adalah orang atau perusahaan yang berfungsi mengorganisir pengiriman barang dari pengirim (mungkin produsen atau pedagang saja) sampai ke konsumen akhir. FF adalah badan usaha yang bertujuan menjual jasa pengiriman atau penerimaan dengan menggunakan multimoda transport baik melalui darat, laut maupun udara.

Dalam transportasi laut FF ini disebut Ekspedisi Muatan Kapal Laut (EMKL). Operasi FF berlaku untuk pengiriman barang melalui semua moda, yaitu 
moda angkutan darat, moda angkutan kereta api, moda angkutan laut, moda angkutan udara, sedangkan EMKL hanya terbatas untuk pengiriman dengan moda angkutan laut saja.

\section{Tugas dan Tanggungjawab Freight Forwarding}

Dalam mengeluarkan dan memasukkan barang dari dan ke kapal, shipper atau consignee sering menggunakan jasa FF karena alasan efisiensi atau keterbatasan ketrampilan. Perusahaan pelayaran menggunakan jasa FF karena alasan efisiensi-profesional. Rentang kegiatannya adalah mengurus muatan dan dokumennya. Pengertian "mengurus" di sini adalah mengelola muatan dan mengelola dokumentasi pengangkutan sehingga pengiriman efektif.

Awal kegiatan FF adalah adanya surat penunjukan (surat kuasa) dari pemilik barang untuk mengurus barangnya. Jika asumsinya outbond logistics (aliran barang keluar), di pelabuhan muat FF membantu pemilik barang membooking ruangan kapal pada agen perusahaan pelayaran tertentu. Lalu mengurus dokumen-dokumen yang diperlukan: invoive, packing list, surat keterangan asal barang (SKA), dan dokumen barang lainnya. Setelah dokumen lengkap lalu mengangkutkan barang dari gudang pemilik barang ke pelabuhan. Setelah sampai di pelabuhan barang dapat diperlakukan : (1) Harus menggunakan gudang pelabuhan untuk ditumpuk sementara sambil menunggu antrian pemuatan ke kapal; (2) Truck lossing, yaitu begitu barang tiba di pelabuhan langsung dimuat ke kapal. Pengertian gudang di sini dapat berupa gudang tertutup untuk menumpuk barang yang loos cargo (muatan umum yang lepas-lepas), atau gudang terbuka container yard untuk muatan petikemas. Jika barang tersebut untuk tujuan ekspor maka FF harus mencari dokumen kepabeanan dengan menghubungi perusahaan pengurusan jasa kepabeanan (PPJK) sampai barang clear. Jika FF juga mempunyai kualifikasi sebagai penyedia jasa kepabeanan tidak perlu menghubungi PPJK, cukup ditangani sendiri. Kalau barang hanya tujuan domestik maka clearance kepabeanan tidak diperlukan.

Aktivitas pemuatan ke kapal sesuai UU No. 17 Tahun 2008 harus dilakukan oleh perusahaan bongkar muat (PBM). Maka FF perlu menghubungi PBM agar barangnya dapat dimuatkan. Dalam banyak kasus di Indonesia, kegiatan memuatkan/ membongkar dilakukan oleh "perusahaan satu atap" yaitu perusahaan yang berfungsi sebagai pengangkut dan sekaligus sebagai penyedia jasa bongkar muat.

Di pelabuhan bongkar, FF membantu pemilik barang membongkar muatan dari kapal, mengeluarkan dari pelabuhan, mengantarkan sampai ke penerima barang lengkap dengan dokumen yang harus diperlukan. Jika barang tersebut adalah barang impor maka juga perlu clearance impor dari kepabeanan, yang bisa ditangani sendiri oleh FF jika mempunyai kwalifikasi atau harus menghubungai PPJK. Sementara jika barang kiriman domestik tak perlu clearance impor (Lasse, 2016).

Sekarang kgiatan FF terintegrasi dengan perusahaan pelayaran dalam cakupan rantai pasok, sebagaimana gambar berikut: 


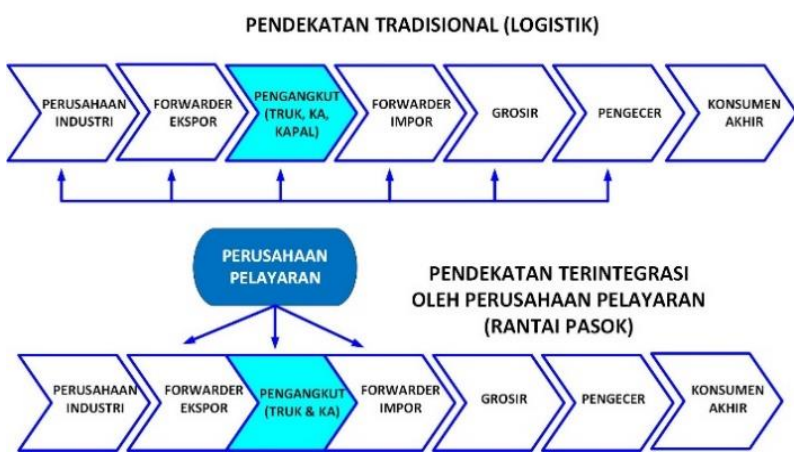

Gambar 1. Kegiatan Freighr Forwarding Terintegrasi dengan Perusahaan Pelayaran

Sumber: Pietro Evangelista \& Alfonso Morvillo (1999)

Pada gambar di atas menunjukkan bahwa kegiatan FF di pelabuhan asal, pengangkutan dengan truk dan kereta api, serta kegiatan FF di pelabuhan tujuan diintegrasikan oleh perusahaan pelayaran.

Pengurusan biaya muatan dengan container oleh FF meliputi: menyelesaikan biaya-biaya yang timbul dari sewa gudang / container freight station-CFS/ container yard -CY, haulage, lift on-off, transportasi, asuransi barang, serta clearance kepebeanan (jika barang ekspor-impor). Biaya-biaya tersebut kemudian akan ditagihkan ke "pembeli jasa", yaitu pengirim atau penertima dengan fee tertentu yang merupakan penghasilan FF.

Rentang kerja FF sangat fleksibel, dapat hanya mengangkutkan saja dari gudang pengirim sampai ke pelabuhan muat atau secara keseluruhan proses sampai barang diterimakan ke penerima di pelabuhan tujuan, atau tergantung batas penyerahan barang sesuai INCOTERM 2010 serta sesuai perintah kerja pemberi order.

Menurut Suyono (2005), tugas FF secara menyeluruh meliputi:

a. Memilih rute perjalanan barang, moda transportasi dan pengangkut yang sesuai, kemudian memesan ruang muat kapal

b. Melakukan penerimaam barang, menyortir, mengepak, mengukur (berat, panjang), menyimpan di gudang

c. Mempelajarai letter of credit $(\mathrm{L} / \mathrm{C})$, peraturan negara tujuan ekspor, negara transit, negara impor, lalu mempersiapkan dokumen-dokumen yang diperlukan

d. Melaksanakan transportasi baik darat, laut maupun udara beserta dokumen transportasi bill of lading (B/L) sampai penyerahan barang

e. Membayar biaya-biya pengangkutan (freight), biaya handling barang, biaya auransi

f. Mengurus pengajuan klaim kepada perusahaan asuransi bila terjadi klaim

g. Memonitor perjalanan barang sampai ke pihak penerima

h. Menerima barang dari perusahaan pengangkut

i. Mengururs clearance in/out ke dan dari pelabuhan, baik barang kiriman domestik maupun barang ekspor/impor. 
Adapun barang-barang yang ditangani oleh FF bervariasi, mulai muatan umum, petikemas, muatan berbahaya, muatan khusus, barang-barang proyek, offshore drilling dan sebagainya. Karena setiap barang tersebut memerlukan alat penanganan khusus (derek, forklift, dan sebagainya), maka kemudian muncul FF khusus pada penangan barang-barang tertentu.

Kewajiban FF sangat luas, yaitu: menjamin pengiriman barang dari tempat asal sampai tujuan terakhir dengan selamat. FF memberi pelayanan yang paling sesuai yang disediakan: angkutan kapal, transportasi melalui darat, pengangkutan udara, container dengan kapasitas besar. Kesesuaian dalam pengepakan, pemenuhan, dan persyaratan berbagai kebijakan. Prosedur fiat muat, termasuk pemenuhan dokumentasi, mengurus asuransi, termasuk kewajiban untuk kondisikondisi tertentu dan jadwal transit dari berbagai bentuk pelayanan transportasi yang tersedia. Juga metode yang paling memuaskan dalam menutup penanganan finansial muatan internasional, seluruh aspek teknikal dalam pengiriman internasional, marking of cargo, dan keadaan/peraturan di negara tujuan yang harus dipenuhi oleh eksportir (Suyono, 2005).

Berdasarkan pembahasan di atas maka fungsi FF sebagai supply chain management (SCM) untuk memenuhi permintaan pelanggan melalui penggunaan sumber daya yang paling efisien, dalam distribusi, persediaan, pengiriman barang secara efektif (Lambert, Stock, Elram, 1998; Christopher, 2011).

\section{Karakteristik Jasa}

Dalam kehidupan sehari-hari masyarakat tidak terlepas dari jasa. Semakin modern kehidupan suatu masyarakat maka akan semakin jasa yang di hasilkan dan dibutuhkan masyarakat (Lovelock and Wirtz, 2004). Hal ini wajar karena profesi masyarakat akan semakin bervariasi, dan sebagian besar profesi tersebut dalam jasa.

Jasa dalam ruang lingkup ini adalah produk dari satu kegiatan masyarakat baik perseorangan atau perusahaan yang diperjual-belikan. Terminologi jasa di antaranya adalah sebagi berikut. Menurut Kotler and Keller (2012) jasa adalah:

"tindakan atau kegiatan yang dapat ditawarkan oleh satu pihak kepada

pihak lain yang pada dasarnya tidak berwujud dan tidak mengakibatkan kepemilikan apapun. Produksinya dapat dikaitkan / tidak dikaitkan dengan suatu produk fisik."

Di sini menekankan klarakteristik bahwa jasa tidak berwujud dan tidak mengakibatkan kepemilikan. Orang yang membeli / mengkonsumsi suatu jasa tidak dapat dibuktikan secara kasat mata. Kemudian jasa ada yang terkait dengan produk dan ada yang tidak terkait dengan produk. Namun sebenarnya tidak tidak ada jasa yang murni tidak terikat dengan produk fisik dan sebaliknya tidak ada produk yang tidak terkait dengan jasa, sehingga jasa secara "wujud" merupakan kontinum antara abstrak sekali sampai fisik sekali (Lovelock and Wirtz, 2004; Zeithaml, Bitner, Gremler, 2006). Perhatikan gambar berikut. 


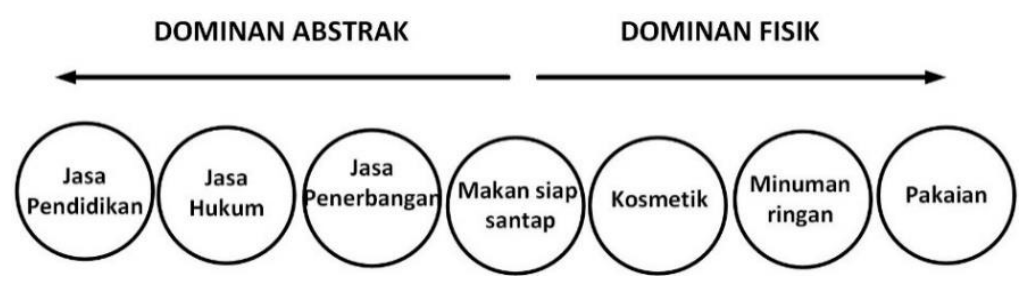

Gambar 2. Kontinum Jasa

Sumber: Lovelock and Wirtz (2004); Zeithaml, et al. (2006), dengan Penyesuaian

Pada gambar di atas menunjukkan bahwa jenis jasa yang arahnya semakin ke kiri semakin abstrak, dan produk yang arahnya semakin ke kanan semakin fisikal. Pengertian semakin abstrak dan semakin fisikal dalam arti tidak abstrak seratus persen atau fisikal seratus persen. Jasa pendidikan misalnya, produknya berupa jasa tentang transfer pengetahuan melalui pengajaran. Jasa pendidikan ini tetap terikat harus ada gedung, kantor dan sebagainya. Demikian sebaliknya produk pakaian, walaupun dominan berupa fisikal tatap memerlukan jasa membangun image tentang mode dari artis misalnya. Sedangkan makanan siap santap adalah contoh produk / jasa hybrid, antara dominan fisik dan dominan abstrak. Buktinya orang-orang jaman sekarang yang makan di gerai makanan siap saji tidak semata-mata untuk keperluan memenuhi kebutuhan mkan saja, namun juga untuk keperluan santai, cengkerama dengan teman dan sebagainya.

Sebagai pandangan lain, Lovelock and Wirtz (2004), memberikan terminologi jasa sebagai berikut:

"A service is an economic activity that creates value and provides benefit for customers at a specific time and place, by bringing about a desired change in, or an behalfoy the recipient of the service."

Jasa adalah suatu kegiatan ekonomi yang menghasilkan nilai dan memberikan manfaat bagi para konsumen pada waktu dan tempat tertentu, dengan menyediakan semua atau sebagian keinginan dari penggunaan jasa tersebut. Kata kuncinya adalah: memberikan nilai, diproduksi dan dikonsumsi pada waktu dan tempat yang sama, sebagai pemuas kebutuhan. berikut:

Menurut Kotler and Keller (2012), jasa mempunyai karakteristik sebagai

a. Tidak berwujud (intangible), tidak kasat mata, tidak dapat dirasakan dan dinikmati sebelum dibeli;

b. Tidak dapat dipisahkan (inseparable), jasa yang diproduksi dan dirasakan pada waktu bersamaan dan apabila dikehendaki oleh seseorang untuk diserahkan kepada pihak lainnya, maka akan tetap merupakan bagian dari jasa tersebut;

c. Bervariasi (variable), jasa selalu mengalami perubahan tergantung dari siapa penyedia jasa dan penerima jasa dan kondisi di mana jasa tersebut diberikan;

d. Tidak tahan lama (perishable), jasa mudah rusak, jika pada waktu tertentu tidak laku terjual tidak dapat di-stock untuk dijual pada waktu lain. 
Berdasarkan uraian di atas maka perusahaan penghasil jasa harus memperhatikan karakteristik jasa yang dihasilkannya agar dapat memenuhi keinginan pelanggannya.

\section{Kualitas Jasa}

Jasa sebagai produk untuk memenuhi kebutuhan dan keinginan pelanggan mempunyai kualitas karena kualitas merupakan salah satu dimensi yang menentukan penilaian kepuasan. Menurut Kotler and Keller (2012), kualitas adalah totalitas fitur dan karakteristik dari produk atau jasa yang memiliki kemampuan untuk memuaskan keinginan yang dinyatakan secara langsung maupun tidak langsung. Hal ini berarti menunjukkan bahwa fitur produk atau jasa menentukan kualitas yang kemudian memuaskan kebutuhan konsumen. Kata kuncinya di sini adalah dapat memuaskan kebutuhan pelanggan.

Kualitas dapat diketahui dengan cara membandingkan persepsi konsumen atas layanan yang nyata diterima dengan layanan yang diharapkan konsumen, di mana persepsi konsumen atas simpulan konsumen yang didapat terutama dari pengalamannya menggunakan produk ataupun jasa yang bersangkutan. Kualitas produk atau jasa menurut Chirthoper (2011) disebut nilai, karena pada prinsipnya sama.

Konsep kualitas itu sendiri dianggap sebagai ukuran relatif kebaikan suatu produk atau jasa yang terdiri atas kualitas desain dan kualitas kesesuaian. Kualitas desain merupakan fungsi spesifikasi produk, sedangkan kualitas kesesuaian merupakan suatu ukuran seberapa jauh suatu produk mampu memenuhi persyaratan atau spesifikasi kualitas yang telah ditetapkan. Pada kenyataannya aspek ini bukanlah satu - satunya aspek kualitas.

Menurut Zeithaml et al. (2006), ada lima dimensi kualitas jasa yang harus dipenuhi oleh penyedia jasa. Kelima dimensi kualitas jasa tersebut adalah sebagai berikut:

1. Reliabilitas (dapat dipercaya)

Artinya kemampuan untuk melaksanakan pelayanan yang dijanjikan secara akurat. Hal ini meliputi pelayanan pada waktu yang telah direncanakan/ditetapkan, akurat dalam perhitungan dan menjaga pelayanan dengan baik dan benar.

2. Daya tanggap

Artinya tanggapan yang cepat dalam memberikan bantuan kepada konsumen dan melaksanakan pelayanan tersebut secara layak. Hal itu meliputi pemberian pelayanan secara tepat dan cepat dan mengatur perjanjian atau penerimaan konsumen dengan cepat dan benar.

3. Jaminan

Artinya pengetahuan, keterampilan, tata krama karyawan dan kemampuan untuk mengembangkan kepercayaan dan keyakinan atau tingkat sopan-santun yang harus dimiliki karyawan untuk menciptakan kepercayaan dan rasa percaya diri konsumen.

4. Empati

Artinya kepedulian dan pemberian perhatian secara individu kepada setiap konsumen. Termasuk di dalamnya adalah mengerti apa yang diinginkan konsumen. Hal ini meliputi kegiatan mempelajari keinginan konsumen, 
memberikan perhatian secara individu kepada konsumen, dan mengenal konsumen secara lebih dekat.

5. Keberwujudan

Artinya penampilan fisik peralatan, personal dan alat-alat komunikasi. Hal itu meliputi penampilan karyawan, fasilitas fisik, peralatan dan perlengkapan yang digunakan dalam pelayanan. Ada wujud fisik sebagai produk pendukung baik sebelum maupun setelah jasa diserhkan ke pelanggan. Misalnya berupa bangunan, interior, seragam pegawai, peralatan yang dipakai, dan sebagainya yang berwujud.

Kelima indikator tersebut merupakan penyederhanaan dimensi-dimensi kualitas jasa agar mudah difahami, karena penulis lain memberikan lebih dari lima dimensi.

Sebagai perbandingan, menurut Oliver (1980), kualitas suatu jasa terdiri atas 3 komponen utama yaitu:

1. Technical quality

Komponen ini berkaitan dengan kualitas hasil layanan yang dipersepsikan konsumen. Komponen ini dibagi menjadi 3 jenis, yaitu: (a) Search quality, yaitu kualitas yang dapat dievaluasi sebelum dibeli, misalnya harga, (b) Experience quality, yaitu kualitas yang dapat dievaluasi setelah dikonsumsi, misalnya kecepatan pelayanan, ketepatan waktu dan kerapian pakaian karyawan, (c) Credence quality, yaitu kualitas yang sulit dievaluasi oleh konsumen sekalipun telah mengkonsumsi kualitas layanan tersebut.

2. Functional quality

Komponen ini berkaitan dengan kualitas cara perusahaan penyedia jasa memberikan layanannya kepada konsumen.

3. Corporate image

Komponen ini berkaitan dengan citra umum, profil, reputasi, dan daya tarik khusus yang dimiliki perusahaan penyedia jasa.

\section{Persepsi Harga}

Bentuk dari alat kebijakan yang digunakan oleh perusahaan dalam menciptakan persepsi harga terdiri dari jaminan uang kembali, harga tetap, harga yang adil, dan informasi mengenai harga (Matzler, Wurtele, and Renzl, 2006). Persepsi harga merupakan persepsi dan pemahaman yang menyenangkan dari konsumen terhadap faktor-faktor yang mempengaruhi harga suatu barang. Menurut Diller (2008), terdapat lima dimensi dari price perception yaitu relative price, price-quality ratio, price transparency, price confidence, price reliability, price fairness. Kata kuncinya di sini terletak pada keadilan harga baik bagi produsen maupun konsumen, jika harga adalah fair maka dimensi-dimensi yang lain akan inklusif.

\section{Kepuasan Pelanggan}

Pengertian kepuasan pelanggan menurut Kotler and Keller (2012), adalah:

"Satisfaction is a person's feelings of pleasure or disappointment resulting from comparing a product's perceived performance (or outcome) in relation to his or her satisfactions." 
Kepuasan dapat terjadi apabila kinerja produk atau jasa sama dengan atau lebih dari harapan konsumen akan produk atau jasa tersebut sedangkan apabila kinerja produk atau jasa tidak memenuhi harapan konsumen akan produk atau jasa maka konsumen akan merasa tidak puas. Jadi kepuasan dapat terjadi apabila kinerja produk atau jasa sama dengan atau lebih dari harapan konsumen, demikian halnya sebaliknya.

Adapun cara mengukur kepuasan konsumen menurut Kotler and Keller (2012) yaitu:

a. Complaint and suggestion systems

Perusahaan membuat sistem kritik dan saran untuk memperbaiki kinerja selama ini untuk memenuhi kepuasan konsumen, misalnya dengan nomor bebas pulsa untuk konsumen dan penggunaan website.

b. Customer satisfaction survey

Melakukan penelitian tkepuasan konsumen terhadap produk atau jasa perusahaan dalam jangka waktu tertentu, seperti halnya yang dilakukan penulis ini.

c. Ghost shopping

Perusahaan dapat menyewa orang-orang yang dapat dijadikan pembeli potensial untuk mengukur dan membuat laporan mengenai kelemahan dan kekuatan produk atau jasa perusahaan dan pesaing.

d. Lost customer analysis

Perusahaan dapat menghubungi konsumen yang sudah menghentikan pemakaian produk atau jasa perusahaan dan telah berpindah ke produk atau jasa perusahaan lainnya untuk mengetahui alasan kenapa beralih dan untuk mengetahui tingkat kehilangan konsumen.

\section{Loyalitas Pelanggan}

Loyalitas secara harfiah berarti kesetiaan seseorang terhadap suatu obyek. Menurut Schiffman and Kanuk (2014), loyalitas merek merupakan hasil yang paling diharapkan dari perilaku konsumen. Bahwa loyalitas merek merupakan suatu preferensi konsumen secara konsisten untuk melakukan pembelian pada merek yang sama pada produk yang spesifikasi atau pelayanan tertentu. Menurut Mowen dan Minor (2001) adalah kondisi di mana pelanggan mempunyai sikap yang positif terhadap suatu merek, mempunyai komitmen terhadap merek tersebut. Oliver (1999) yang menyatakan, bahwa loyalitas merek merupakan komitmen yang teguh untuk membeli ulang atau berlangganan dengan produk atau jasa yang disukai secara konsisten dimasa datang, sehingga menimbulkan pembelian merek atau rangkaian merek yang sama secara berulang, meskipun pengaruh situasional dan upaya pemasaran berpotensi untuk menyebabkan perilaku beralih merek.

Schiffman dan Kanuk (2014), menerangkan bahwa komponen loyalitas merek terdiri atas empat macam, yaitu:

a. Kognitif

Merupakan representasi dari apa yang dipercayai oleh konsumen. Komponen kognitif ini berisikan persepsi, kepercayaan dan stereo-type seorang konsumen mengenai suatu merek. Loyalitas berarti bahwa konsumen akan 
setia terhadap semua informasi yang menyangkut harga, segi keistimewaan merek dan atribut-atribut penting lainnya. Konsumen yang loyal dari segi kognitif akan mudah dipengaruhi oleh strategi persaingan dari merekmerek lain yang disampaikan lewat media komunikasi khususnya iklan maupun pengalaman orang lain yang dikenalnya serta pengalaman pribadinya.

b. Afektif

Merupakan komponen yang didasarkan pada perasaan dan komitmen konsumen terhadap suatu merek. Konsumen memiliki kedekatan emosi terhadap mrek tersebut. Loyalitas afektif ini merupakan fungsi dari perasaan (affect) dan sikap konsumen terhadap sebuah merek seperti rasa suka, senang, gemar, dan kepuasan pada merek tersebut. Konsumen loyal secara afektif dapat bertambah suka dengan merek-merek pesaing apabila merekmerek pesaing tersebut mampu menyampaikan pesan melalui asosiasi dan bayangan konsumen yang dapat mngarahkan mereka kepada rasa tidak puas terhadap merek yang sebelumnya.

c. Konatif

Merupakan batas antara dimensi loyalitas sikap dan loyalitas perilaku yang direpresentasikan melalui kecenderungan perilaku konsumen untuk menggunakan merek yang sama di kesempatan yang akan datang. Komponen ini juga berkenaan dengan kecenderungan konsumen untuk membeli merek karena telah terbentuk komitmen dalam diri mereka untuk tetap mengkonsumsi merek yang sama. Bahaya-bahaya yang mungkin muncul adalah jika para pemasar merek pesaing berusaha membujuk konsumen melalui pesan yang menantang keyakinan mereka akan merek yang telah mereka gunakan sebelumnya.

d. Tindakan

Merupakan rekomendasi atau mempromosikan merek tertentu kepada orang lain. Konsumen yang loyal secara tindakan akan mudah beralih kepada merek lain jika merek yang selama ini ia konsumsi tidak tersedia di pasaran. Loyal secara tindakan mengarah kepada tingkah laku mempromosikan merek tersebut kepada orang lain.

\section{METODE PENELITIAN}

\section{Jenis Penelitian}

Penelitian ini causal method, untuk menguji hubungan antar variabel dugaan sementara (hipotesis). Variabel yang diuji adalah service quality, dan customer satisfaction dengan loyalty. Jenis variabel:

a. Variabel independen, yaitu variabel yang menjadi sebab terjadinya atau terpengaruhinya variabel dependen, dalam hal ini kualitas pelayanan (service quality).

b. Variabel perantara (intervening), yaitu variabel yang berada di antara variabel independen dan dependen, dalam hal ini kepuasan pelanggan (buyer satisfaction).

c. Variabel dependen, yaitu variabel yang nilainya dipengaruhi oleh variabel independen, dalam hal ini loyalitas pelamnggan (buyer loyalty). 


\section{Definisi dan Operasional}

a. Service quality, merupakan perbandingan persepsi konsumen atas layanan yang terdiri atas layanan yang nyata diterima dengan layanan yang diharapkan konsumen, di mana persepsi konsumen atas simpulan konsumen yang didapat terutama dari pengalamannya menggunakan jasa yang bersangkutan.

b. Customer satisfaction, kepuasan dapat terjadi apabila kinerja jasa sama dengan atau lebih dari harapan konsumen sedangkan apabila kinerja jasa tidak memenuhi harapan konsumen maka konsumen akan merasa tidak puas.

c. Brand loyalty, merupakan suatu preferensi konsumen secara konsisten untuk melakukan pembelian pada merek yang sama pada produk atau jasa tertentu.

\section{Sampel Penelitian}

Sampel penelitian adalah konsumen PT. Mustikakencana Sakti, pengumpulan dengan accidental sampling diperoleh 50 responden dan yang layak dianalisis 49 responden.

\section{Model Penelitian}

Model penelitian ini mengikuti topik yang dibangun penulis, mencari hubungan antar variabel atau causal method sebagaimana gambar berikut.

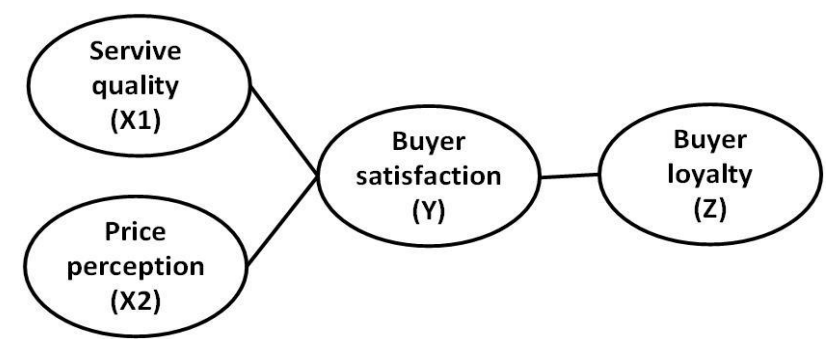

Hubungan yang ingin diuji adalah service quality (X1) dan price perception (X2) terhadap buyer satisfaction (Y), dan buyer satisfaction (Y) terhadap buyer loyalty $(\mathrm{Z})$.

\section{Metode Analisis}

\section{Uji Validitas}

Uji validitas menggunakan rumus korelasi product moment sebagai berikut:

\section{Uji Reliabilitas}

Uji reliabilitas berguna untuk menetapkan apakah instrumen (kuesioner) dapat digunakan lebih dari satu kali, paling tidak oleh responden yang sama (Sekaran, 2003). Pengukuran reliabilitas dalam penelitian ini dilakukan dengan cara one shot atau pengukuran sekali.

\section{Uji Asumsi Klasik}

Uji statistik ini dilakukan untuk mengetahui tingkat normalitas, multikolinearitas dan heteroskedastisitas, dilakukan dengan bantuan program SPSS (Statistical Package For The Social Sciences) 20 For Windows. 
a. Uji Normalitas

Uji normalitas menggunakan uji Kolmogorov Smirnov, untuk mengetahui normalitas distribusi data, apakah data berdistribusi normal atau tidak. Apabila data berdistribusi normal, maka pengujian selanjutnya akan dilakukan dengan uji statistik parametrik. Apabila data berdistribusi tidak normal, maka pengujian selanjutnya akan dilakukan dengan uji statisitik non parametrik.

Adapun hipotesis pengujiannya :

$\mathrm{HO}$ : data berdistribusi normal.

H1 : data tidak berdistribusi normal.

Dengan kriteria pengujian:

Jika asymp sig. pada output Kolmogorov Smirnov > 5\%, maka data terdistribusi normal, dan jika $<5 \%$, maka data tidak terdistribusi normal.

b. Uji Multikolinearitas

Uji multikolinearitas digunakan untuk mengetahui apakah terjadi hubungan linear di antarara variabel-variabel independen. Dalam analisis regresi berganda, terdapat dua atau lebih variabel bebas yang diduga akan mempengaruhi variabel tergantungnya. Di antara variabel bebas harus benar-benar tidak terjadi hubungan linear. Deteksinya menggunakan

Variance Inflation Factor (VIF) untuk masing-masing variabel independen, yaitu jika suatu variabel independen mempunyai nilai VIF > 10 berarti telah terjadi multikolinearitas.

c. Uji Heterokedastisitas

Uji heterokedastisitas digunakan untuk menguji apakah dalam model regresi linear kesalahan pengganggu (e) mempunyai varians yang sama atau tidak dari satu pengamatan ke pengamatan yang lain. Untuk menguji heterokedastisitas dapat diketahui dari nilai signifikan korelasi Rank Spearman antara masing-masing variabel independen dengan residualnya. Adapun kriteria pengujiannya, sebagai berikut :

Nilai signifikan $>\alpha(5 \%)$ maka tidak terdapat heteroskedastisitas Nilai signifikan $<\alpha(5 \%)$ maka terdapat heteroskedastisitas.

\section{Uji Hipotesis}

a. Uji Parsial (Uji T)

Uji ini digunakan untuk menentukan signifikansi pengaruh masing-masing variabel bebas harga (X1) dan kualitas pelayanan (X2) terhadap kepuasan pelanggan (Y). Deteksinya membandingkan antara nilai t hitung dengan nilai t tabel.

$\mathrm{t}$ tabel $=\{\alpha: \mathrm{df}(\mathrm{n}-\mathrm{k})\}$

thitung $=\ldots$..

Keterangan:

$\alpha$ : Level of significance, atau probabilitas menolak hipotesis yang benar.

$\mathrm{n}$ : Jumlah sampel yang diteliti 
$\mathrm{k}$ : Jumlah varibel independen termasuk konstanta se : Standar error

Uji t-statistik yang dilakukan menggunakan uji satu sisi secara parsial dengan $\alpha=5 \%(0.05)$ atau tingkat keyakinan 95\%, sedangkan df $=n-k$, dengan $\mathrm{n}$ adalah ukuran sampel.

Kriteria pengujian:

Jika t hitung > t tabel berarti H0 ditolak dan H1 diterima, atau variabel independen berpengaruh signifikan terhadap variabel dependen.

Jika t hitung < t tabel berarti $\mathrm{H} 0$ diterima dan $\mathrm{H} 1$ ditolak, atau variabel independen tidak berpengaruh terhadap variabel dependen.

Formulasi hipotesis : $\mathrm{H} 0: \beta 1=0, \beta 2=0$

$$
\mathrm{H} 1: \beta 1 \neq 0, \beta 2 \neq 0
$$

\section{b. Uji Simultan (Uji F)}

Uji $F$ digunakan untuk mengetahui pengaruh dari variabel independen secara keseluruhan terhadap variabel dependen. Deteksinya membandingkan nilai $\mathrm{F}$ hitung dengan nilai $\mathrm{F}$ ta-bel.

$\mathrm{F}$ hitung $=\ldots .$.

F tabel $=(\alpha: k-1, n-k), \alpha=5 \%$

Di mana:

$\mathrm{R}$ : Koefisien determinasi

$\mathrm{n}$ : Banyaknya responden

$\mathrm{k}$ : Banyaknya variabel bebas

Kriteria Pengujian :

$\mathrm{H} 0: \beta 1=\beta 2=0$, artinya $\mathrm{X}_{1}$ dan $\mathrm{X}_{2}$ tidak berpengaruh simultan dan signifikan terhadap

Y

$\mathrm{H} 1: \beta 1 \neq \beta 2 \neq 0$, artinya $\mathrm{X}_{1}$ dan $\mathrm{X}_{2}$ berpengaruh simultan dan signifikan terhadap Y

\section{d. Hipotesis}

$\mathrm{H1}$ : Variabel kepuasan pelanggan berpengaruh terhadap variabel loyalitas. H0 : $\rho_{1}=0$ : Kepuasan tidak berpengaruh secara signifikan terhadap loyalitas.

H2 : Variabel kualitas pelayanan berpengaruh terhadap variabel loyalitas.

H0 : $\rho_{2}=0:$ Kualitas pelayanan tidak berpengaruh secara signifikan terhadap loyalitas.

H3 : Variabel kepuasan pelanggan dan variabel kualitas pelayanan berpengaruh terhadap variabel loyalitas.

H0 : $\rho_{12}=0$ : Kepuasan pelanggan dan kualitas pelayanan tidak berpengaruh secara simultan terhadap loyalitas. 


\section{Uji Korelasi Ganda (R)}

Pengujian ini digunakan untuk mengetahui hubungan antara dua atau lebih variabel independen terhadap variabel dependen secara serentak. Koefisien ini menunjukkan seberapa besar hubungan yang terjadi antara variabel independen secara serentak terhadap variabel dependen. Nilai $\mathrm{R}$ berkisar antara 0 hingga 1 , nilai semakin mendekati1 berarti hubungan yang terjadi semakin kuat, sebaliknya nilai semakin mendekati 0 maka hubungan yang terjadi semakin lemah.

Rumus korelasi ganda dengan dua variabel independen adalah :

Keterangan:

Ry. $\mathrm{x}_{1} \mathrm{x}_{2}$ : Korelasi variable $\mathrm{X} 1$ dengan $\mathrm{X} 2$ secara bersama-sama dengan $\mathrm{Y}$

ryx $_{1} \quad$ : Korelasi sederhana (pearson product moment) antara X1 dengan $\mathrm{Y}$

ryx $_{2}$ : Korelasi sederhana (pearson product moment) antara X2 dengan $Y$

$\mathrm{rx}_{1} \mathrm{x}_{2} \quad$ : Korelasi sederhana (pearson product moment) antara $\mathrm{X} 1$ dan $\mathrm{X} 2$

\section{HASIL DAN PEMBAHASAN}

Berdasarkan observasi dan dokumentasi diperoleh hasil yang menggambarkan deskripsi umum PT. Mustikasakti Saranakencana yang ditunjukkan oleh volume muatan dan jangkauan wilayah pengiriman, kemudian data dari survey diperoleh hasil uji.

\section{Deskripsi Umum Muatan yang Ditangani}

\section{Volume Muatan yang Ditangani}

Bahwa jasa yang ditawarkan oleh PT. Mustikasakti Saranakencana sebagai perusahaan freight forwarding sebagian besar dalam bentuk jasa pengiriman muatan. Adapun volume muatan yang ditangani rata-rata ditunjukkan sebagaimana tabel berikut:

Tabel 1. Rata-Rata Muatan yang Ditangani

\begin{tabular}{lcc}
\hline $\begin{array}{c}\text { Bobot muatan } \\
(\mathbf{K g})\end{array}$ & Frekuensi & $\begin{array}{c}\text { Persentase } \\
(\boldsymbol{\%})\end{array}$ \\
\hline $0-100$ & 13 & 26,5 \\
\hline $100-500$ & 13 & 26,5 \\
\hline $500-1000$ & 5 & 10,2 \\
\hline $1000-5000$ & 6 & 12,2 \\
\hline$>5000$ & 12 & 24,5 \\
\hline Jumlah & 49 & 100 \\
\hline
\end{tabular}

Sumber: Data Diolah 
Berdasarkan tebel di atas mayoritas bobot muatan yang dikirim antara 100-500 $\mathrm{Kg}$ kemudian di atas $500 \mathrm{Kg}$. Hal ini dapat difahami bahwa orang yang yang mengirim barang / muatan berat cenderung diserahkan oleh fihak lain agar efektif.

\section{Wilayah Jangkauan Pengiriman} berikut:

Wilayah jangkauan pengiriman muatan ditunjukkan sebagaimana tabel

Tabel 2. Jangkauan Pengiriman Muatan

\begin{tabular}{lcc}
\hline \multicolumn{1}{c}{ Jangkauan } & Frekuensi & $\begin{array}{c}\text { Persentase } \\
(\%)\end{array}$ \\
\hline Lokal / Dalam Kota & 4 & 8,2 \\
\hline Antar Kota & 4 & 8,2 \\
\hline Antar Pulau & 21 & 42,9 \\
\hline Antar Negara & 20 & 40,8 \\
\hline Jumlah & 49 & 100 \\
\hline
\end{tabular}

Sumber: Data Diolah

Berdasarkan pengamatan dan dokumentasi jangkauan wilayah pengiriman mayoritas adalah antar pulau dan antar negara (ekspor-impor). Hal ini masuk akal mengingat Indonesia sebagai negeri kepulauan (UU No. 17 Tahun 2008), sehingga pengiriman muatan yang berat sebagaimana Tabel 1 sebelumnya dan tujuan pengirimannya jauh / antar pulau dan ekspor-impor lebih efisien dan efektif diserahkan kepada fihak lain dalam hal ini perusahaan freight forwarding.

\section{Hasil Uji}

\section{Uji Validitas dan Reliabilitas}

Pertama hasil uji validitas dan reliablitas sebagaiman ditunjukkan pada tabel berikut.

Tabel 3. Validitas dan Reliabiltas Service Quality

\begin{tabular}{lcc}
\hline $\begin{array}{c}\text { Constructs } \\
\text { and indicators }\end{array}$ & $\begin{array}{c}\text { Standardized } \\
\text { factor loadings }\end{array}$ & Keputusan \\
\hline OS1 & 0,438 & Valid \\
\hline OS2 & 0,306 & Valid \\
\hline OS3 & 0,688 & Valid \\
\hline PSERV1 & 0,422 & Valid \\
\hline PSERV2 & 0,469 & Valid \\
\hline PSERV3 & 0,087 & Tidak Valid \\
\hline
\end{tabular}


MIBJ Vol. 18 No. 1, Februari 2020 | Ivan Reyhansyah

\begin{tabular}{lll}
\hline TSERV1 & 0,413 & Valid \\
\hline TSERV2 & 0,408 & Valid \\
\hline TSERV3 & 0,835 & Valid \\
\hline
\end{tabular}

Sumber : Data Diolah

Berdasarkan tabel 3 dapat diketahui bahwa masing-masing indikator pada variabel service quality masih terdapat indikator yang memiliki nilai factor loading < 0,3 pada PSERV3, sehingga indikator tersebut tidak diikutsertakan dalam model penelitian.

Tabel 4. Validitas dan Reliabiltas Satisfaction

\begin{tabular}{ccc}
\hline $\begin{array}{c}\text { Constructs } \\
\text { and indicators }\end{array}$ & $\begin{array}{c}\text { Standardized factor } \\
\text { loadings }\end{array}$ & Keputusan \\
\hline S1 & 0,621 & Valid \\
\hline S2 & 0,697 & Valid \\
\hline S3 & 0,682 & Valid \\
\hline
\end{tabular}

Sumber : Data Diolah

Berdasarkan tabel 4 dapat diketahui bahwa masing-masing indikator pada variabel satisfaction dinyatakan valid dan reliabel, nilai loading factor $>0,30$ (Hair et al. 2010), menunjukkan semua indikator dapat menjelaskan konstruk yang ada.

Tabel 5. Validitas dan Reliabiltas Loyalty

\begin{tabular}{ccc}
\hline $\begin{array}{c}\text { Constructs } \\
\text { and indicators }\end{array}$ & $\begin{array}{c}\text { Standardized } \\
\text { factor loadings }\end{array}$ & Keputusan \\
\hline Loyalty1 & 0,688 & Valid \\
\hline Loyalty2 & 0,688 & Valid \\
\hline Loyalty3 & 0,873 & Valid \\
\hline
\end{tabular}

Sumber : Data Diolah

Berdasarkan tabel 5 dapat diketahui bahwa masing-masing indikator pada variabel loyalty dinyatakan valid dan reliabel, nilai loading factor $>0,30$ (Hair et al. 2010), menunjukkan semua indikator dapat menjelaskan konstruk yang ada.

\section{Uji Realibilitas Data}

Uji reliabilitas menggunakan Cronbach's Alpha sebagai koefisien dari reliabilitas. 
Hasil uji reliabilitas sebagaimana tabel berikut:

Tabel 6. Uji Reliabilitas Data

\begin{tabular}{lcc}
\hline \multicolumn{1}{c}{ Variabel } & Cronbach Alpha & Keputusan \\
\hline Service Quality & 0,791 & Reliabel \\
\hline Satisfaction & 0,718 & Reliabel \\
\hline Price Perception & 0,630 & Reliabel \\
\hline Loyalty & 0,922 & Reliabel \\
\hline
\end{tabular}

Sumber : Data Diolah

Hasil koefisien reliabilitas (alpha) yang tertera pada tabel 6 dapat dikatakan bahwa instrument yang digunakan andal, dapat dipercaya untuk digunakan sebagai alat pengumpul data. Koefisien seluruh variabel lebih besar dari 0,6, sehingga pertanyaan dalam kuesioner layak digunakan (reliable).

\section{Uji Multikoliniearitas}

Pengujian multikolinearitas dapat dilakukan sebagai berikut: tolerance value $<0,10$ atau VIF $>10$ : terjadi multikolinearitas, tolerance value $>0,10$ atau VIF < 10 : tidak terjadi multikolinearitas. Dari hasil uji ditunjukkan pada tabel berikut :

Tabel 7. Uji Multikolinieritas

\begin{tabular}{lcc}
\hline \multicolumn{1}{c}{ Variabel } & VIF & Keputusan \\
\hline Service & 1.632 & $\begin{array}{c}\text { Tidak ada } \\
\text { Multikolinearitas }\end{array}$ \\
\hline Satisfaction & 1.612 & $\begin{array}{c}\text { Tidak ada } \\
\text { Multikolinearitas }\end{array}$ \\
\hline Price & 1.023 & $\begin{array}{c}\text { Tidak ada } \\
\text { Multikolinearitas }\end{array}$
\end{tabular}

Sumber : Data Diolah

Berdasarkan tabel 7 terlihat bahwa hubungan linier antar variabel independen lebih kecil dari 10, artinya tidak terjadi multikolinearitas yang kuat dalam model regresi.

\section{Analisis Regresi Linear Berganda}

Hasil pengujian regresi linier berganda ditunjukkan pada tabel berikut : 
Tabel 8. Hasil Pengujian Regresi Berganda

\begin{tabular}{|c|c|c|c|c|c|c|c|c|}
\hline \multicolumn{9}{|c|}{ Coefficientsa } \\
\hline \multirow{2}{*}{\multicolumn{2}{|c|}{ Model }} & \multicolumn{2}{|c|}{$\begin{array}{l}\text { Unstandardized } \\
\text { Coefficients }\end{array}$} & \multirow{2}{*}{$\begin{array}{c}\text { Standardized } \\
\text { Coefficients } \\
\text { Beta } \\
\end{array}$} & \multirow[b]{2}{*}{$\mathrm{t}$} & \multirow[b]{2}{*}{ Sig. } & \multicolumn{2}{|c|}{ Collinearity Statistics } \\
\hline & & $\mathrm{B}$ & Std. Error & & & & Tolerance & VIF \\
\hline 1 & (Constant) & -.418 & .857 & & -.487 & .628 & & \\
\hline & Service & .285 & 172 & 212 & 1.661 & 104 & .613 & 1.632 \\
\hline & Satisfacton & .871 & .190 & .583 & 4.589 & .000 & .620 & 1.612 \\
\hline & Price & -.074 & 146 & -.051 & -.508 & .614 & 977 & 1.023 \\
\hline
\end{tabular}

a. Dependent Variable: Loyalty

Dari hasil tabel 8 di atas didapatkan persamaan regresinya sebagai berikut:

$\mathrm{Y}=-0,418+0,285$ Service Quality $+0,871$ Satisfaction $-0,074$ Price

Keterangan :

$\mathrm{Y}=$ Loyalty

$\mathrm{X}_{1} \quad=$ Service Quality

$\mathrm{X}_{2} \quad=$ Satisfaction

$\mathrm{X}_{3}=$ Price

Persamaan regresi di atas dapat dijelaskan sebagai berikut:

a. Bahwa konstanta sebesar $-0,418$ artinya jika variabel $X_{1}, X_{2}$ dan $X_{3}$ nilainya adalah 0 , maka loyalty $(\mathrm{Y})$ nilainya adalah $-0,418$. Artinya bahwa $\mathrm{X} 1, \mathrm{X} 2$ dan X3 secara bersama-sama berkorelasi positif terhadap Y.

b. Koefisien regresi variabel Service Quality (X1) sebesar 0,285, artinya jika $\mathrm{X}_{1}$ mengalami kenaikan $1 \%$ maka nilai $\mathrm{Y}$ akan mengalami peningkatan sebesar 0,285 dengan asumsi variabel independen lain nilainya tetap. Koefisien bernilai positif artinya terjadi hubungan positif antara variabel Service Quality $\left(\mathrm{X}_{1}\right)$ dengan Loyalty ( $\left.\mathrm{Y}\right)$.

c. Koefisien regresi variabel Satisfaction (X2) sebesar 0,871 , artinya jika $\mathrm{X}_{2}$ mengalami kenaikan $1 \%$ maka nilai $\mathrm{Y}$ akan mengalami peningkatan sebesar 0,871dengan asumsi variabel independen lain nilainya tetap. Koefisien bernilai positif artinya terjadi hubungan positif antara variabel Satisfaction $\left(\mathrm{X}_{2}\right)$ dengan Loyalty $(\mathrm{Y})$.

d. Koefisien regresi variabel Price (X3) sebesar -0,074, artinya jika $\mathrm{X}_{3}$ mengalami kenaikan $1 \%$ maka nilai $\mathrm{Y}$ akan mengalami penurunan sebesar 0,074 dengan asumsi variabel independen lain nilainya tetap. Koefisien bernilai negatif artinya terjadi hubungan negatif antara variabel Price $\left(\mathrm{X}_{3}\right)$ dengan Loyalty (Y).

\section{Hasil Uji Hipotesis}

\section{Uji F}

Uji $\mathrm{F}$ atau uji serentak atau uji model Anova, yaitu uji untuk melihat bagaimanakah pengaruh semua variabel bebasnya bersama-sama terhadap variabel terikatnya. Hasil pengujian F ditunjukkan pada tabel berikut.

Tabel 9. Hasil Uji F

Majalah Ilmiah Bahari Jogja 98 | http://jurnal.amy.ac.id/index.php/MIBJ/ 
ANOVA

\begin{tabular}{|ll|r|r|r|r|c|}
\hline Model & & \multicolumn{1}{|c|}{$\begin{array}{c}\text { Sum of } \\
\text { Squares }\end{array}$} & \multicolumn{1}{c|}{$\mathrm{df}$} & Mean Square & \multicolumn{1}{c|}{$\mathrm{F}$} & Sig. \\
\hline 1 & Regression & 3.870 & 3 & 1.290 & 18.291 & $.000^{\mathrm{a}}$ \\
& Residual & 3.173 & 45 & .071 & & \\
& Total & 7.043 & 48 & & & \\
\hline
\end{tabular}

a. Predictors: (Constant), Price, Satisfacton, Service

b. Dependent Variable: Loyalty

Sumber : Data Diolah

Berdasarkan tabel 9 diperoleh nilai $\mathrm{F}$ tabel dengan tingkat signifikan $\alpha=5 \%$ dengan nilai signifikan sebear $0,000 / 2=0,000<0,05$, artinya dapat diterima. Hasil ini menunjukkan variabel Service (X1), Satisfaction (X2) dan Price (X3) secara bersama-sama berpengaruh terhadap loyalty (Y).

\section{Uji T}

Uji t yaitu untuk menguji keberartian koefisien variabel bebas secara parsial terhadap variabel terikat. Deteksinya operasional hipotesis sebagai berikut:

a. Sig $\leq 0,05$, maka $\mathrm{H} 0$ ditolak dan Ha diterima

Artinya variabel bebas mempengaruhi secara signifikan terhadap variabel terikat.

b. Sig $\geq 0,05$, maka $\mathrm{H} 0$ diterima dan Ha ditolak

Artinya variabel bebas tidak mempengaruhi variabel terikat, ataupun dapat mempengaruhi tetapi tidak signifikan.

Pada intinya, semakin kecil signifikansi suatu variabel independen menunjukkan semakin dominan variabel independen tersebut terhadap variabel dependennya.

Adapun hasil uji T pada hipotesis sebagai berikut:

Tabel 10. Hasil Uji Hipotesis

\begin{tabular}{lccc}
\hline \multicolumn{1}{c}{ Hipotesis } & Koefisien $\boldsymbol{\beta}$ & $\boldsymbol{p}$-value & Keputusan \\
\hline $\begin{array}{l}\text { H1: Diduga terdapat pengaruh service quality } \\
\text { terhadap customer satisfaction }\end{array}$ & 0,285 & $\begin{array}{l}0,104 / 2 \\
=0,052\end{array}$ & Berpengaruh \\
\hline $\begin{array}{l}\text { H2: Diduga terdapat pengaruh price } \\
\text { perception terhadap customer satisfaction }\end{array}$ & $-0,074$ & $\begin{array}{l}0,614 / 2 \\
=0,307\end{array}$ & $\begin{array}{l}\text { Tidak } \\
\text { Berpengaruh }\end{array}$ \\
\hline $\begin{array}{l}\text { H3: Diduga terdapat pengaruh customer } \\
\text { satisfaction terhadap buyer loyalty }\end{array}$ & 0.871 & 0.000 & Berpengaruh \\
\hline
\end{tabular}

Sumber: Data Diolah

\section{Hipotesis 1}

Hasil uji menunjukkan bahwa hipotesis pertama menunjukkan nilai signifikan sebesar 0,052 < 0,1 sehingga keputusannya adalah Ho ditolak. Maka dapat dinyatakan terdapat pengaruh service quality terhadap customer satisfaction. 
Adapun pengaruhnya adalah positif dengan nilai sebesar 0,285 yang menunjukkan pelayanan yang baik akan meningkatkan kepuasan konsumen.

Temuan penelitian ini mendukung dan penelitian sebelumnya yang mengidentifikasikan berbagai faktor yang menentukan tingkat kepuasan pelanggan. Pentingnya pengaruh kualitas jasa terhadap kepuasan konsumen (Cronin and Taylor, 1992; Taylor and Baker, 1994). Demikian juga tingkat kepuasan pelanggan sebagai faktor penelitian yang berhubungan dengan tingkat kualitas layanan jasa (Parasuraman et al.1985,1988,1991,1994; Carman,1990; Bitner,1990), dan bahwa tingkat kualitas layanan jasa tidak sama dengan tingkat kepuasan (Oliver,1980).

\section{Hipotesis 2}

Hasil uji menunjukkan bahwa hipotesis kedua menunjukkan nilai signifikan sebesar 0,307>0,05 sehingga keputusannya adalah Ho diterima. Maka dapat dinyatakan tidak terdapat pengaruh price perception terhadap customer satisfaction.

Temuan penelitian ini tidak mendukung penelitian sebelumnya yang dilakukan oleh Herman (2007), di mana pengguna jasa membandingkan harga perolehan mereka dengan perolehan dari exchange partner-nya (Oliver, 1980; Oliver, 1999). Konsumen merasa sebuah kenaikan harga sebagai sesuatu yang tidak adil, jika mereka beranggapan hal tersebut hanya akan bertindak untuk menaikkan keuntungan. Lebih lanjut lagi, pembeli merasa sebuah pertukaran itu tidak adil jika mereka mengetahui bahwa pembeli yang lain yang memiliki hubungan pertukaran dengan penjual yang sama mendapatkan harga yang lebih rendah untuk produk yang sama (Hermaan, 2007).

\section{Hipotesis 3}

Hipotesis ketiga yang menganalisis pengaruh customer satisfaction terhadap customer loyalty menunjukkan nilai signifikan sebesar $0,000<0,05$, sehingga keputusannya Ho ditolak. Maka dapat dinyatakan terdapat pengaruh customer satisfaction terhadap customer loyalty. Adapun pengaruhnya adalah positif dengan nilai sebesar 0,871 yang menunjukkan konsumen yang puas akan menjadi konsumen yang setia.

Hasil penelitian ini mendukung penelitian sebelumnya yang menunjukkan pentingnya dimensi tingkat kualitas layanan jasa dalam menentukan tingkat kepuasan pelanggan (Levesque and McDougall,1996), dan selanjutnya tingkat kepuasan pelanggan pada retail berdampak terhadap terciptanya kesetiaan pelangan dan berdampak terhadap loyalitas. Demikian juga bahwa peningkatan kepuasan konsumen akan menunjukkan pengaruh signifikan pada tingkat kesetiaan pelanggan (Bitner, Booms, and Mohr,1994; Anderson, Fornell, and Lehmann,1994).

\section{SIMPULAN}

Terdapat pengaruh service quality terhadap customer satisfaction, pelayanan yang baik akan meningkatkan kepuasan pelanggan. Tidak terdapat pengaruh price perception terhadap customer satisfaction, harga yang ditawarkan tidak mempengaruhi kepuasan pelanggan. Terdapat pengaruh customer satisfaction terhadap customer loyalty, pelanggan yang puas akan menjadi pelanggan setia. 


\section{DAFTAR PUSTAKA}

Anderson, E.W., Fornell, C., and Lehmann, D.R., (1994). Customer satisfaction, market share and profitability, Journal of Marketing, 58 (3): 53-66.

Bitner, M.J., (1990). Evaluating service encounters: the effects of physical surroundings and employee responses, Journal of Marketing, 54 (2): 6982.

Bitner, M.J., Booms, B.H., and Mohr, L.A., (1994). Critical service encounters: the employees viewpoint, Journal of Marketing, 58 (4): 95-106.

Carman, J.M., (1990). Consumer perceptions of service quality: an assessment of the SERVQUAL dimensions, Journal of Retailing, 66 (1): 33-55.

Christopher, M., (2011). Logistics \& Supply Chain Management, Forth Edition. Harlow: Prentice Hall.

Cronin, J.J., Taylor, S.A., (1992). Measuring servicequality: a reexamination and extension, Journal of Marketing, 56 (3): 55-68.

Diller, H., (2008). Price fairness, Journal of Product \& Brand Management, 17 (5): $353-355$.

Evangelista, P., and Morvillo, A., (1999). Alliances in liner shipping: an instrument to gain operational efficiency or supply chain integration ?, International Journal of Logistics: Research and Applications, 2 (1): 2138.

Hermawan, A., (2007). Pedoman Praktis Metodologi Penelitian Bisnis, LPFE.

Kotler, P., Amstrong, G., (1994). Principles of Marketing, Englewood Cliffs: Prentice- Hall.

Kotler, P., Keller, K.L., (2012). Marketing Management, New Jersey: Prentice Hall Inc.

Lambert, D.M., Stock, J.R., Elram, L.M., (1998). Fundamentals of Logistics Management, Boston: McGraw-Hill.

Lasse, D.A., (2016). Manajemen Muatan - Aktivitas Rantai Pasok di Area Pelabuhan, Jakarta: RajaGrafindo Persada.

Levesque, T., and McDougall, G.H.G., (1996). Determinants of customer satisfaction in retail banking, International Journal of Bank Marketing, 14 (7): $12-20$.

Lichtenstein, D.R., Ridgway, N.M., and Netemeyer, R.G., (1993). Price perceptions and consumer shopping behavior: a field study, Journal of Marketing Research, 30, (2): 234-245.

Lovelock, C., and Wirtz, J., (2004). Services Marketing, Fifth Edition. Singapore: Pearson Prentice Hall.

Matzler, K., Wurtele, A., and Renzl, B., (2006). Dimensions of price satisfaction: a study in the retail banking industry, International Journal of Bank Marketing, 24 (4): 216-231.

Mowen, J.C., dan Minor, M., (2001). Perilaku Konsumen, (Terjemahan), Bandung: PT. Penerbit Erlangga.

Oliver, R.L., (1980). A cognitive model of the antecedent and consequences of satisfaction decisions, Journal of Marketing, 17 (10): 460-469.

Oliver, R.L. (1999). Whence Consumer Loyalty?, Journal of Marketing, 63 (4): 33-44.

Majalah Ilmiah Bahari Jogja 101 | http://jurnal.amy.ac.id/index.php/MIBJ/ 
Parasuraman, A., Berry, L., and Zeithaml, V.A., (1985). A conceptual model of SQ and its implications for future research, Journal of Marketing, 49: 4150 .

Parasuraman, A., Zeithaml, V.A., and Berry, L.L., (1988). SERVQUAL: a multiple-item scale for measuring consumer perceptions of service quality, Journal of Retailing, 64 (1): 12-40.

Parasuraman, A., Berry, L. and Zeithaml, V.A., (1991). Perceived service quality as a customer-based performance measure: an empirical examination of organizational barriers using an extended service quality model, Human Resource Management, 30 (3): 335-364.

Parasuraman, A., Berry, L. and Zeithaml, V.A., (1994). Reassessment of expectations as a comparison standard in measuring SQ: implications for future research, Journal of Marketing, 58 (1): 111-124.

Porter, M.E., (1980), Competitive Strategy : Techniques for Analyzing Industries and Competitors, New York: The Free Press.

Rodrigue, , J.P., Comtois, C., and Slack, B., (2006). The Geography of Transport System, New York: Routledge.

Sekaran, U., (2003), Research Methods for Business: A Skill Building Approach. New York: John Wiley \& Sons.

Schiffman, G.L., and Kanuk L.L, (2014). Consumer Behavior, Englewood Cliffs: Prentice- Hall.

Suyono, R.P., (2005). Shipping Pengangkutan Intermodal Ekspor Impor Melalui Laut, Jakarta: PPM.

Taylor, S.A. and Baker, T.L., (1994). An assessment of the relationship between service quality and customer satisfaction in the formation of consumer's purchase intentions, Journal of Retailing, 70 (2):163-178.

Zeithaml, V.A., Bitner, M.J., Gremler, D.D., (2006). Services Marketing Integrating Customer Focus Across the Firm, New York: McGraw-Hill.

Undang-Undang Nomor 17 Tahun 2008 tentang Pelayaran.

Peraturan Menteri Perhubungan Nomor 49 Tahun 2017 tentang Penyelenggaraan dan Pengusahaan Jasa Pengurusan Transportasi. 